DOI 10.37882/2223-2974.2020.11.30

\section{ON THE CLASSIFICATION OF PARLIAMENTARY REPUBLICS}

\section{A. Siushkin}

Summary: The article is devoted to the problem of classifying a parliamentary republic as a form of government. The parliamentary Republic as a form of government is represented by a significantly smaller number of countries than the presidential and mixed republics, which causes a small number of its types. The author singles out the classic parliamentary republics of the European type; republics with direct presidential elections, which is seen as a deviation from the classical form; atypical parliamentary republics, which include countries with a significant shift in the balance of the branches of government in favor of the legislative and the absence of a sole head of state, as well as ethnoconfessional parliamentary republics, characteristic, first of all, of the countries of the Middle East. The article also analyzes the reasons for the formation of each type of parliamentary republic.

Keywords: state, forms of state, forms of government, republic, parliamentary republic.

\title{
К ВОПРОСУ О КЛАССИФИКАЦИИ ПАРЛАМЕНТСКИХ РЕСПУБЛИК
}

\begin{abstract}
Сиушкин Альберт Евгеньевич
К.с.н., доцент, Пензенский государственный университет bert_s@mail.ru

Аннотация: Статья посвящена проблеме классификации парламентской республики как формы правления. Данная форма представлена значительно меньшим количеством стран, чем президентская и смешанная республики, что обусловливает незначительное количество ее типов. Автор выделяет классические парламентские республики европейского типа; республики с прямыми выборами президента, что рассматривается как отклонение от классической формы; атипичные парламентские республики, к которым относятся страны с значительным смещением баланса ветвей власти в пользу законодательной и отсутствием единоличного главы государства, а также этноконфессиональные парламентские республики, характерные, прежде всего, для стран Ближнего Востока. Также в статье анализируются причины становления каждого типа парламентской республики.
\end{abstract}

Ключевые слова: государство, формы государства, формы правления, республика, парламентская республика.

ропейские республики парламентского типа, которыми являются, например, такие государства как Германия и Италия.

Так, в Германии существует два высших представительных (законодательных) органа. Первый - Бундестаг - не только формирует законодательство страны, но и предоставляет через своих, непосредственно избранных народом, депутатов демократическую легитимность всем другим конституционным и государственным органам. Это касается, в первую очередь, главы правительства, избираемого Бундестагом.

Вторым высшим представительным органам Германии является Бундесрат, члены которого назначаются и отзываются органами исполнительной власти федеральных земель.

Наличие двух высших представительных органов в системе государственного управления Германии обусловлено федеративных характером этого государства и необходимостью сочетания в законодательной и исполнительной сферах интересов всего населения страны с интересами отдельных территорий независимо от их размера и количества населения.

Прежде всего, следует выделить классические ев- 
Высокая роль парламента в Германии также во многом обусловлена стремлением предотвратить в стране возрождение авторитаризма и нацизма, для чего после Второй мировой войны исполнительная власть конституционным путем была поставлена под жесткий контроль парламента.

Как и в других странах, где формой правления выступает парламентская республика, парламент Германии осуществляет формирование и контроль над деятельностью исполнительной власти в лице Федерального правительства. В Германии установлена двухступенчатая процедура формирования правительства. В начале Бундестаг избирает его главу - Федерального канцлера. Кандидатура, одобренная путем переговоров парламентским большинством, предлагается для утверждения Федеральным президентом. После избрания и назначения канцлер может начать формирование своего правительства.

Роль правительства в Германии и особенно канцлера очень велика. В соответствии со ст. 65 Основного закона ФРГ канцлер «определяет основные направления политики и несет за это ответственность», а также «ведет дела правительства». Компетенция канцлера определять основные направления политического развития Германии позволяет ему быть фактическим главой государства. В этой связи Германию часто называют «канцлерской республикой». [1, с. 340]

Одной из главных особенностей функционирования парламентской республики выступает особое положение президента, который в условиях этой модели организации политической власти, будучи главой государства, не является главой исполнительной власти и обладает в основном представительно-церемониальными полномочиями, осуществляемыми по инициативе либо с согласия правительства.

Президент ФРГ избирается на пять лет путем косвенных выборов Федеральным собранием. Федеральное собрание - временный орган, создаваемый с целью избрания главы государства. Он состоит из членов Бундестага и делегатов, избранных представительными органами земель (ландтагами).

По Конституции Германии Федеральный президент обладает определенными полномочиями, в частности:

- подписывает и оглашает федеральные законы;

- выдвигает кандидатуру федерального канцлера на рассмотрение парламента;

- утверждает канцлера в должности и освобождение его от должности;

- также утверждает и освобождает от должности федеральных министров, федеральных судей и др.
Однако, в большинстве случаев для вступления в действие распоряжений и указаний Президента необходима их контрассигнация (заверение) Федеральным канцлером или компетентным Федеральным министром (ст. 58 Основного закона ФРГ).

Типичной парламентской республикой в настоящее время является также Республика Италия. Парламентский тип правления в этой стране исторически опосредован рядом факторов. Италия - регионалистское государство с довольно обширным перечнем прав для своих областей, развитыми традициями самоуправления и широкого участия в политике частных организаций, в том числе профсоюзов и католической церкви.

Как и в Германии Парламент Италии состоит из двух палат: Палаты депутатов и Сената. Обе палаты избираются населением. Есть также ряд пожизненных сенаторов (бывшие президенты страны и иные лица), назначаемые главой государства.

К конституционно закрепленным функциям парламента относятся: законотворчество, парламентский контроль за деятельностью правительства, определение основных направлений внутренней и внешней политики, выборы Президента Республики и др. Под контролем парламента находятся практически все вопросы политики, проводимой государством, он может принимать по ним резолюции.

Правительство (Совет министров) Италии - главный исполнительный орган, отражающий компромисс наиболее влиятельных партий. Председатель правительства - является ключевой фигурой, которая определяет политику государства. Председатель назначается Президентом Республики, министры также назначаются Президентом по предложению Председателя. При этом согласно ст. 94 Конституции Итальянской республики Правительство обязательно должно получить доверие обеих палат не позднее десяти дней после сформирования. Таким образом, в отличие от Германии, где кандидатуры министров утверждаются после назначения канцлера, в Италии, назначение премьер-министра и министров носит характер общего пакетного соглашения между ведущими партиями и коалициями парламента, а президент выступает консультативным и ратифицирующим звеном.

Избрание Президента Италии происходит на совместном заседании двух палат парламента. Полномочия Президента Италии в своем большинстве идентичны полномочиям Президента ФРГ. Значительными функциями президента Италии являются:

- назначение парламентских выборов;

- роспуск парламента (по представлению спикеров палат); 
- назначение премьер - министра и министров;

- промульгация законов.

Из перечисленного относительной самостоятельностью Президент пользуется лишь в вопросе роспуска парламента. В соответствии со статьей 88 Конституции Итальянкой республики он может, «заслушав председателей палат, распустить обе палаты или одну из них». Роспуск может состояться после выражения вотума недоверия правительству, или в целях стабилизации политического положения в стране и даже с согласия самого парламента, например, если до очередных выборов больше не планируется рассмотрение важных законопроектов, т.е. в последнем случае носить технический характер.

Таким образом, Германию и Италию можно справедливо считать классическими парламентскими республиками с главенствующей политической ролью парламента, значительной властью премьер-министра (главы правительства) и очень слабой властью президента (главы государства).

Отдельно выделим парламентские республики с прямыми выборами президента. К таким республикам относится, например, Исландия. Глава государства здесь не реализует своих полномочий самостоятельно, а «осуществляет свою власть через министров» (ст. 13 Конституции Исландии), и все его акты подлежат контрассигнации одним из членов правительства (ст. 19 Конституции Исландии). Роль президента в политическом процессе носит формальный характер. Единственное его реальное полномочие - возможность наложения законодательного вето, которое, однако, ни разу не применялось на практике.

Президент Исландии избирается всенародным голосованием, но сами выборы во многом носят церемониальный характер. Так, если зарегистрирован только один кандидат, то он считается законно избранным без голосования (ст. 5 Конституции Исландии). Из 19 выборов Президента, имевших место в истории Исландии, 11 не состоялись в силу того, что у единственного кандидата не было соперников. Политические партии в избирательном процессе не участвуют.

В Австрии Федеральный Президент избирается на всеобщих выборах с 1957 года. В отличие от Исландии, выборы президента Австрии являются партийными (кандидаты пользуются поддержкой партий) и, как правило, конкурентными.

Несмотря на конкурентный характер выборов, полномочия Президента Австрии характерны для глав государств в парламентских республиках. Все его действия осуществляются на основании предложений правитель- ства, а решения должны быть скреплены подписью федерального канцлера или компетентного федерального министра (ст. 67 Федерального конституционного закона Австрии). Реальным лидером страны является Федеральный канцлер, назначаемый Президентом с учетом расстановки политических сил в парламенте.

Также прямые выборы президента существуют в парламентских республиках Болгарии, Румынии, Словении и Финляндии.

Институт прямых президентских выборов в перечисленных странах рассматривается обычно как отклонение от «чистой» парламентской системы поскольку считается, что при такой форме правления президент не должен избирается народом. Однако, примеры парламентских республик, где существуют выборы президента населением на практике не единичны. Кроме того, дискуссии по поводу необходимости перехода к прямым выборам главы государства имеют место в Германии и Италии.

Сторонники такой реформы к числу «плюсов» всеобщих президентских выборов относят: повышение легитимности президентской власти; превращение президента в активную политическую фигуру и повышение его роли в политическом процессе; предотвращение ситуации, когда президент выражает интересы политических партий, а не более широких групп населения, а также ситуации, когда президенты становятся «продуктом» «сделок» между партиями; преодоление отчуждения граждан от власти и политики; повышение явки на выборах и преодоление усталости избирателей.

Противники перехода к прямым выборам президента в парламентской республике считают, что такого рода выборы больше подходят президентским и полупрезидентским системам, а не парламентским, в которых президент «царствует, но не правит», и слабый статус президента в парламентской системе больше соотносится с тем, что его избирает парламент, а не народ. Кроме того, прямые выборы - не гарантия независимости президента от партий, а президент, избранный от партии, может управлять независимо. [2, с.82]

Далее выделим нетипичные парламентские республики. К ним, в частности, мы относим форму правления с значительным смещением баланса ветвей власти в пользу законодательной. В этих странах отсутствует единоличный глава государства. Пример: Франция в начале I Республики (1793 г.) Современная модель - политическое устройство Швейцарии. В научной литературе достаточно распространенным является мнение, что по форме правления такие страны нельзя назвать традиционными парламентскими республиками. Их часто определяют как «суперпарламентские» [3], 
«директоральные» [4], «коллегиальные президентуры» [5], «ассамблеи» [6] и т.п.

Рассмотрим политическое устройство Швейцарии. В этой стране законодательным органом Федеральное собрание, состоящее из двух палат - Национального совета (нижняя палата) и Совета Кантонов (верхняя палата). Конституция Швейцарии характеризует Федеральное собрание как орган, обладающий верховной властью при соблюдении прав народа и кантонов (ст. 148 Конституции Швейцарии).

Исполнительная власть в Швейцарии осуществляется Федеральным советом - высшим исполнительным органом страны, который состоит из семи членов. Члены совета избираются Федеральным Собранием на четыре года. Во главе совета стоит Федеральный Президент, также избираемый парламентом на один год. Федеральный Совет - коллегиальный орган. Он руководит Федеральной администрацией, состоящей из федеральных департаментов, возглавляемых членами Совета (ст. 177).

Федеральный Президент не имеет важных политических привилегий. Основными его функциями являются решение процедурных вопросов работы Совета и поддержание отношений между федеральной и местной властью при решении общих вопросов. По сути Президент Швейцарии не является ни главой государства, как это принято в классических парламентских республиках, ни главой Федерального Совета, так как основная власть сконцентрирована в руках всех членов данного исполнительного органа. В этой связи Швейцарию можно рассматривать как парламентскую республику, где единоличный глава государства фактически отсутствует, а его функции включены в компетенцию высшего коллегиального исполнительного органа.

На наш взгляд, генезис парламентской формы правления в европейских странах был связан с ростом притязаний на власть европейской буржуазии, для которой парламент всегда представлялся наиболее действенным институтом участия в политической жизни и контроля государства. Заметное влияние на этот процесс также оказала историческая практика британской политической системы, оформившейся в современном виде примерно в XVII-XVIII вB. Недаром в научной литературе распространены упоминания о сходстве статусов британского монарха и президента парламентской республики.

Однако, сегодня парламентские республики существуют и за пределами Старого Света. Причины их становления часто принципиально иные. Как правило это национальные и религиозные противоречия, средством урегулирования которых и выступает парламентская форма правления. При этом в данных странах мы можем наблюдать эрозию классических республиканских институтов, например, отступление от привычной европейской модели разделения властей, распределение мест в парламенте, исходя из установленных законом квот и т.п. Такие нетипичные парламентские республики условно определим как этноконфессиональные.

Так, своеобразная политическая модель политического устройства сложилась в Израиле. Высшим законодательным органом этого государства является Кнессет. Главой страны - Президент, избираемый Кнессетом на семь лет. Он также не имеет существенной власти, его обязанности большей частью церемониальные. Реальные полномочия принадлежит Правительству во главе с Премьер-министром).

Израиль в целом придерживается парламентской системы правления, но принцип разделения властей не соблюдается в этом государстве в той же мере, как в европейских странах. Так, на всем протяжении израильской истории подавляющее большинство членов правительства одновременно были и депутатами парламента, что не противоречит законам этой страны.

Интересно также и то, что с 1996 по 2001 год Премьерминистр Израиля, избирался гражданами напрямую, выборы главы правительства проходили параллельно с парламентскими. Благодаря этому в Израиле, всегда считавшемся классической парламентской республикой, сложилась уникальная ситуация, когда рядом с президентом, избранным парламентом, действовал всенародно избранный глава правительства.

Парламентская форма правления в Израиле обусловлена рядом факторов - во-первых, необходимостью согласования многонациональных интересов внутри страны (в первую очередь интересов евреев и арабского населения), во-вторых, сторонников концепций светского (ратующих за Конституцию как основной закон государства) и теократического (отрицающих необходимость другого свода законов, кроме Торы) правления. Несомненно и влияние модели политического устройства Великобритании, управлявшей Палестиной (будущей территорией Израиля) на основании мандата Лиги Наций с 1922 по 1947 гг.

Еще одним ближневосточным государством с нетипичной парламентской формой правления является Ливан. Политическую систему Ливана называют многоконфессиональной. Власть организована согласно религиозному делению общества. По неформальной договоренности представители всех религиозных общин имеют в государстве определенные политические должности. Важнейшие посты распределены следующим образом:

- президентом должен являться христианин-маронит; 
- премьер-министром - мусульманин-суннит;

- спикером парламента - мусульманин-шиит.

Законодательная власть представлена Собранием (Ассамблеей) представителей - парламентом Ливана, который состоит из 128 депутатов, избираемых прямым голосованием на четырёхлетний срок. За христианами и мусульманами закреплено равное число мест. В Собрании заседают 64 мусульманина (27 суннитов, 27 шиитов, 8 друзов и 2 алавита) и 64 христианина (32 маронита, 20 армян Армянской апостольской церкви, 2 армянокатолика, 7 православных, 1 греко-католик (мелькит), 1 протестант, а также ещё 1 по усмотрению). Парламент избирает президента, утверждает состав правительства, утверждает законы и бюджет республики. По конфессиональному признаку также распределены посты в правительстве, административном аппарате и армии. [7, C.115-116]

Президент Ливана избирается путем тайного голосования депутатов парламента сроком на 6 лет. Согласно Конституции, Президент является символом единства страны и имеет ряд незначительных полномочий. В частности, Президент республики промульгирует законы после их одобрения парламентом и обеспечивает их публикацию (ст. 51 Конституции Ливанской республики). Что касается актов самого Президента, то они обязательно скрепляется соответствующим министром или министрами.

Исполнительная власть в республике представлена Правительством Ливана во главе с Премьер-министром. Президент утверждает предложенную кандидатуру главы Правительства после обязательных консультаций с председателем парламента (ст. 53). Премьер-министр в свою очередь формирует сам кабинет также по принципу религиозного квотирования.

Парламентская форма правления в Ливанской Республике является средством преодоления глубоких противоречий между конфессиями - противоречий настолько сильных, что в свое время они привели к кровопролитной гражданской войне (1975-1990). Как пишет в этой связи А.В. Сарабьев, «жизнеспособность ливанского государства и устойчивость его многосоставного общества <...> обязаны его уникальной социально-политической системе <...>», которая «заключает в себе благоприятные для принятия компромиссных решений и их эффективности условия. В ней заложены институциональные предпосылки для сотрудничества, казалось бы, разрозненных и даже противопоставленных друг другу социальных групп ...». [8, с. 92-93]

\section{$* * *$}

Итак, парламентская республика как форма правления отличается определенным многообразием. Она востребована в тех странах, где сложилась поликратическая модель государственной системы с множеством центров генерации общественных интересов и принятия политических решений. Причины становления данных моделей существенно отличаются, что и обусловливает, на наш взгляд, наличие разных видов парламентской республики, в том числе нетипичных. Тенденцией конституционного развития последних является стремление преодолеть недостатки и ограничения классического европейского варианта распределения политических полномочий между ветвями и институтами власти, сделав в конечном счете государственный механизм более гибким и стабильным.

\section{ЛИТЕРАТУРА}

1. Чиркин, В.Е. Сравнительное государствоведение: учеб. пособие / В.Е. Чиркин. - Москва: Норма: ИНФРА-М, 2019. - 448 с.

2. Зазнаев 0.И. Институт прямых президентских выборов в парламентских республиках. // Изв. Сарат. ун-та. Нов. сер. Сер. Социология. Политология. 2018. - Т. 18, вып. 1. - С. 82-86.

3. Касаткина Е.М. Три ветви власти Швейцарской Конфедерации. // Сборник материалов межрегиональной научно-практической конференции с международным участием. - Елец, 2017. - С. 139-142.

4. Петрова М.А. Органы центральной власти современной Швейцарии: тенденции развития. Автореферат диссертации на соискание учёной степени кандидата юридических наук. Москва, 2014. - 29 с.

5. Михайлова Е.М., Пушкарев С.В. Коллективный глава как форма управления государством. // Социальная политика и социология. - №3 (69). - 2011. - С. 128-138.

6. Политология / А.Ю. Мельвиль и др. - М., 2013. - 624 с.

7. Горбунова Н.М. Ливанский кризис: трансформация общества и государства. // ВОСTOK (ORIENS). - 2013. - № 4. - С. 114-122.

8. Сарабьев А.В. Ливан: обыкновенная «консоциональная демократия» в региональном контексте. // Вестник МГИм0-Университета. - 2019. - 12(4). - С. 89-112.

(c) Сиушкин Альберт Евгеньевич (bert_s@mail.ru).

Журнал «Современная наука: актуальные проблемы теории и практики» 